\title{
Deep neck infections of non-odontogenic origin: clinical manifestation and treatment
}

\section{Ropnie głębokie szyi pochodzenia niezębopochodnego: objawy kliniczne i leczenie}

\author{
Katarzyna J. Błochowiak¹, Bartłomiej Kamiński², Jerzy Sokalski \\ ${ }^{1}$ Department of Oral Surgery, Poznan University of Medical Sciences, Poznan, Poland \\ Head of the Department: dr hab. n. med. Jerzy Sokalski \\ 2Otolaryngology Ward, District Hospital im. Maria Sklodowska-Curie in Skarżysko-Kamienna, Poland \\ Head of the Ward: dr n. med. Bartłomiej Kamiński
}

Medical Studies/Studia Medyczne 2018; 34 (1): 98-102

DOI: https://doi.org/10.5114/ms.2018.74828

Key words: parapharyngeal abscess, retropharyngeal abscess, deep neck infection, pharyngitis, peritonsillar abscess.

Słowa kluczowe: ropień przygardłowy, ropień zagardłowy, głębokie infekcje szyi, zapalenie migdałków, ropień

okołomigdałkowy.

\begin{abstract}
Deep neck abscesses of non-odontogenic origin are characterised by different microbiological and clinical manifestations. Based on clinical presentations, the possible complications and results of different methods of treatment were described. We present five cases of non-odontogenic deep neck infections. Computed tomography was used to confirm the diagnosis and monitor the treatment's effectiveness. In three cases, the cause of infection was unidentified, while in the remaining cases pharyngitis and sialoadenitis were non-odontogenic causes of infection. Usually the causative flora were not identified, but in the remaining cases Streptococcus anginosus and Eschericha coli predominated. Computed tomography is the most recommended diagnostic method to detect infection and monitor its progression and treatment. The choice of surgical approach depends on the location of the abscess and its progression. Empirical antibiotic therapy provides additional medical support and complements surgical treatment. Diabetes is an important predisposing factor of deep neck infections.
\end{abstract}

\section{Streszczenie}

Ropnie głębokie szyi pochodzenia niezębopochodnego charakteryzują się różnym obrazem mikrobiologicznym i klinicznym. Na podstawie serii przypadków zostały przedstawione ich możliwe komplikacje i wyniki różnych metod leczenia. Zaprezentowano 5 przypadków ropni głębokich szyi pochodzenia niezębopochodnego. Tomografia komputerowa pozwoliła na potwierdzenie diagnozy i monitorowanie efektywności leczenia. $W$ trzech przypadkach przyczyna infekcji została niezidentyfikowana, w pozostałych przypadkach wykryto zapalenie gardła i zapalenie ślinianek. Flora przyczynowa nie została w większości zidentyfikowana, w pozostałych przypadkach dominowały Streptococcus anginosus i Eschericha coli. Tomografia komputerowa jest rekomendowana metoda w diagnostyce oraz monitorowaniu progresji infekcji i efektów jej leczenia. Wybór metody chirurgicznej zależy od lokalizacji ropnia i jego progresji. Antybiotykoterapia empiryczna stanowi uzupełnienie leczenia. Cukrzyca jest ważnym czynnikiem predysponującym do rozwoju tego typu infekcji.

\section{Introduction}

Deep neck infections can be categorised as parapharyngeal, peritonsillar, or retropharyngeal abscess, according to the site of infection. They belong to the group of upper respiratory tract (URT) and head and neck infections, and comprise the most common group of deep neck abscesses. Most develop secondary to an oropharyngeal or dental infection. The possible causes of pharyngeal abscesses include odontogenic infections (gingivitis, periodontitis, necrotizing ulcerative gingivitis, and periodontal abscess), acute and chronic otitis media, mastoiditis and sinusitis, pharyngo-tonsillitis, suppurative thyroiditis, cervical lymphadenitis, parotitis, sialoadenitis, and deep neck infections including Lemierre's syndrome $[1,2]$. Their management is similar. Untreated abscesses can rupture spontaneously into the pharynx, causing catastrophic aspiration. Other complications are extension of infection laterally to the side of the neck or dissection into the posterior mediastinum through facial planes and the prevertebral space. Death can occur from aspiration, airway obstruction, erosion into major blood vessels, or extension to the mediastinum [3]. The most important issue is a fast diagnosis and proper treatment to avoid serious complications. 
Table 1. Clinical and microbiological characteristics and management of patients with deep neck abscesses ${ }^{a}$

\begin{tabular}{|c|c|}
\hline Characteristics & $n=5$ \\
\hline Male : female & $4: 1$ \\
\hline Mean age (yr) & 55 \\
\hline \multicolumn{2}{|l|}{ Laboratory tests in the onset of infection: } \\
\hline CRP (mg/dl) & $133.113 \pm 64.25$ \\
\hline $\mathrm{ESR}(\mathrm{mm} / \mathrm{hr})$ & $58.8 \pm 37.72$ \\
\hline WBC & $14.93 \pm 1.83$ \\
\hline \multicolumn{2}{|l|}{ Clinical presentation } \\
\hline Odynophagia & $5(100)$ \\
\hline Neck pain/mass & $5(100)$ \\
\hline Dyspnoea & $2(40)$ \\
\hline Trismus & $1(20)$ \\
\hline Oedema of submandibular glands & $1(20)$ \\
\hline Compromised patients (diabetes) & $2(40)$ \\
\hline Symptoms in computed tomography & $\begin{array}{l}\text { Airless/constricted pear blossom } 2 \text { (40), thicker folding lithosphere folds } 1 \text { (20), } \\
\text { swollen mucous membranes of the low/posterior throat, oedema } \\
\text { of the lateral wall of the throat } 2 \text { ( } 40 \text { ), strengthening of the abscess wall } \\
\text { after contrast } 3(60) \text {, enhancement of the mandible and masticatory } \\
\text { muscles } 2(40)\end{array}$ \\
\hline \multicolumn{2}{|l|}{ Management } \\
\hline Tracheostomy & $2(40)$ \\
\hline Antibiotics & Gentamycin 4 (80), metronidazole 4 (80), cefuroxime 4 (80), ceftazidime 1 (20) \\
\hline Surgery (I\&D) & $3(60)$ \\
\hline Endoscopic aspiration & $2(40)$ \\
\hline Excision of submandibular glands & $1(20)$ \\
\hline Microbiology & $\begin{array}{c}\text { Unidentified bacteria } 3 \text { (60), Streptococcus anginosus } 2 \text { (40), } \\
\text { Escherichia coli } 1 \text { (20) }\end{array}$ \\
\hline Cause & Unidentified 3 (60), pharyngitis/tonsillitis 1 (20), sialoadenitis chronica 1 (20) \\
\hline
\end{tabular}

${ }^{a}$ Data presented as mean \pm standard deviation or $n(\%)$.

$I \& D$ - incision and drainage, CRP - C reactive protein, ESR - erythrocyte sedimentation rate, WBC - white blood cells

The aim of this study was to assess the clinical manifestations, causes, and microbiological diagnosis of non-odontogenic deep neck infections. Based on the clinical presentations, the possible complications and results of different methods of treatment were described. The main clinical manifestations were described and the indications for use of different treatment methods were specified.

\section{Case description}

The study comprised five patients (four men and one woman) diagnosed with deep neck infection. Patients were treated in the Department of Oral
Surgery, Poznan University of Medical Sciences and the Department of Otolaryngology at the District Hospital in Skarzysko-Kamienna. All the subjects were of Caucasian origin. The median age of the patients was 55 years. Table 1 presents the demographic, laboratory, microbiological, and clinical profile of deep neck infection patients and summarises the performed treatment. The patients' history was taken and physical and dental examinations were performed for each subject. Laboratory assessments included routine measurements of ESR, WBC, and CRP. Clinical examinations included computed tomography (CT) to confirm the diagnosis. Additionally, 


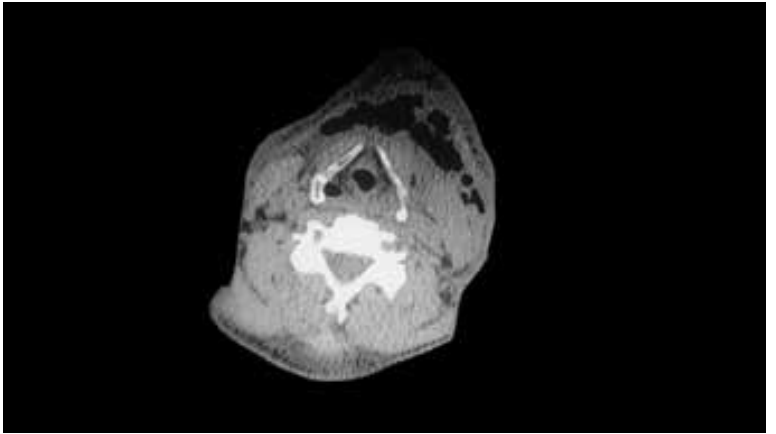

Figure 1. Extensive inflammatory infiltrate with gas blisters in the front of the neck

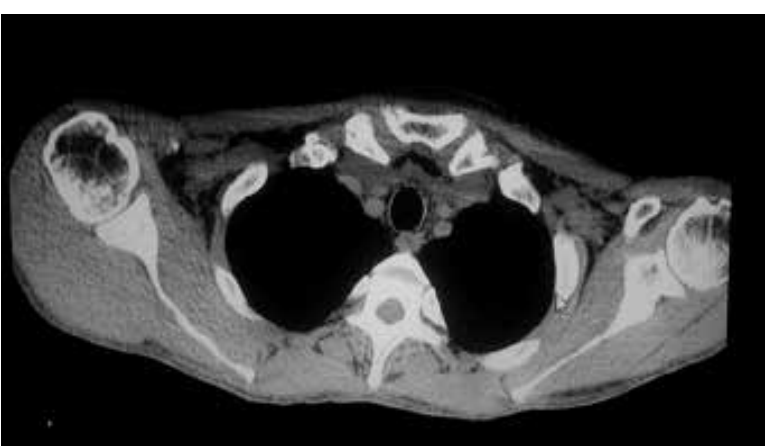

Figure 2. Inflammatory infiltration penetrating the anterior mediastinum

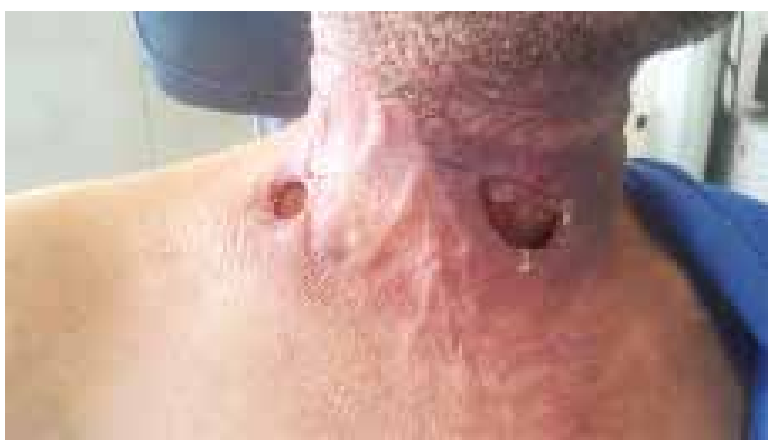

Figure 3. Diffuse neck phlegmone - status after drainage

CT was performed to monitor recovery and treatment effectiveness. Treatment included either extraoral or intraoral incision and drainage, endoscopic aspiration, tracheotomy, and empirical or targeted antibiotic therapy (Figures 1-3).

\section{Discussion}

Dental infections are still treated as the most common cause of deep neck abscesses, followed by pharyngo-tonsillar infections. All cases of deep neck abscesses need comprehensive physical and dental examination to exclude a possible odontogenic source of infection. The infection rarely originates from salivary glands or epiglottitis, and the primary cause of infection cannot be identified in many cases. In the cases we presented the primary cause was not identified and did not originate from the pharynx, tonsils, or submandibular glands. The primary infections should be treated effectively to stop the possible spread of infection. Deep neck infections of nonodontogenic origin are characterised by different clinical and microbiological manifestations compared to odontogenic infections. Dental infections are typically associated with a higher incidence of anaerobic bacteria compared to infections of non-dental aetiology [4]. Trismus is a rare symptom of non-odontogenic deep neck infection and can be very helpful in differentiating odontogenic and non-odontogenic infections. In the process of diagnosing deep neck abscesses, $\mathrm{CT}$ is the most helpful method. Our patients underwent $\mathrm{CT}$ to detect and localise the abscess and then, after incision, to assess the regression of infiltration. In Table 1 we present the most common symptoms of deep neck abscesses in CT. A CT scan is used to confirm the presence of deep neck abscesses, but its accuracy has some limitations, especially in children [2]. On the other hand, the sensitivity and specificity of lateral neck radiograph and ultrasonography are low compared with the specificity for evaluating the fluid-fluid level seen on the CT scan, sensitivity to the presence of a definable abscess wall, and sensitivity to the presence of a prominent wall [5]. In our opinion, CT is the most sensitive and effective diagnostic method for deep neck abscesses and should be performed in all cases. Endogenous oropharyngeal anaerobes are commonly recovered in head and neck infections [1]. The bacterial spectrum of deep neck abscesses is typically polymicrobial, including both aerobic and anaerobic bacteria. The most common aerobic organisms playing a causative role are Streptococcus viridans, $\beta$-haemolytic Streptococcus, Staphylococcus aureus, and Klebsiella pneumonie. The most common anaerobic bacteria are Peptostreptococcus sp., Bacteroides sp., Prevotela sp., and Fusobacterium sp. It is difficult to determine only one causative bacteria species in deep neck abscesses. Anaerobes are difficult to recover and are frequently overlooked. Their exact role is difficult to determine because of the inconsistent methodologies that were utilised for their isolation and identification in many studies. Their recovery and identification require appropriate methods of collection, transportation, and cultivation of specimens [1]. According to Lee et al., Klebsiella pneumoniae, Streptococcus milleri group (SMG) bacteria, and anaerobic bacteria not otherwise specified (NOS) are the main pathogens. Klebsiella pneumoniae was the commonest organism cultured in parapharyngeal space abscesses, while in the submandibular space and parotid space the most commonly isolated are SMG bacteria and 
Staphylococcus aureus, respectively [6]. In our opinion, it is difficult to identify causative bacteria species, and the primary source of infection is determined by microbiological examination. Another very interesting issue is the influence of severe systemic diseases as a predisposing factor of deep neck infections. Two of our patients suffered from uncontrolled diabetes. Uncontrolled diabetes can be treated as a predisposing factor for severe fascial space infections. According to Hasegawa et al., oral disorders can develop deep neck infection independently of the presence of diabetes mellitus, in contrast to other causes. On the other hand, the presence of diabetes mellitus is associated with deep neck infection, aggravating parotitis, and the extensive spread of inflammation [7]. Diabetic patients tend to have complications, tracheostomy, or intubation more frequently as well as a hospital stay of longer duration. In our opinion, deep neck abscesses in compromised patients could be an indication for referral to hospital. Lack of appropriate treatment and collaboration with diabetic patients increase the risk of severe systemic complication and infection. The elimination of all active and potential sources of infection, both odontogenic and non-odontogenic, is very important in compromised patients and decreases the potential risk of severe complications. The most common organism in diabetic patients is Klebsiella pneumoniae $[8,9]$. Older age and underlying systemic diseases increase the mortality in cases of deep neck infections [9]. Infections due to Streptococcus milleri group (SMG), especially Streptococcus anginosus, tend to form abscesses independently of diabetes mellitus [10]. Infections with Streptococcus anginosus are an important predisposing factor of deep neck infections such as parapharyngeal and retropharyngeal abscesses. These species of bacteria show drug resistance to some sorts of antibiotics and their infections should be treated surgically [10]. Surgical drainage is the therapy of choice. Early surgical drainage remains the main method of treating deep neck abscesses. Therapeutic needle aspiration and conservative medical treatment are effective in selective cases, such as those with minimal abscess formation $[10,11]$. In our cases, endoscopic aspiration was the most effective method in well localised, less severe abscesses. Adequate drainage with accompanying antimicrobial therapy and hydration are the cornerstones of management. Catheter or needle drainage of these abscesses may provide an alternative to open procedures and are the drainage methods of choice for peritonsillar abscesses. However, in selected cases, medical therapy alone, especially in children, can resolve parapharyngeal and hypopharyngeal abscesses [2]. We applied cephalosporins and metronidazole or cephalosporins, metronidazole, and gentamicin. Our recommended scheme of empirical antibiotics included cefuroxime (1.5 $\mathrm{g}$ i.v. three times daily) with metronidazole ( $0.5 \mathrm{~g}$ i.v. three times daily) or cefuroxime and metronidazole with gentamycin (0.08 g i.v. two times daily). In one case we applied ceftazidime ( $2 \mathrm{~g}$ i.v. once daily). Our course of antibiotics was effective and it limited the progression and spread of infection. Unidentified causative bacteria species require empirical antibacterial therapy with the use of two or three different antibiotics to widen its antibacterial action and its effectiveness.

\section{Conclusions}

Deep neck abscesses require comprehensive examination to detect odontogenic and non-odontogenic causes of infection. Non-odontogenic infections present a different microbiological and clinical picture. Computed tomography is the most recommended diagnostic method to detect infection and monitor its progression and treatment. Diabetes mellitus, especially when uncontrolled, is an important predisposing factor of deep neck abscesses. Microbiology and clinical manifestation of deep neck abscesses in diabetic patients differs compared to nondiabetic patients. The choice of surgical approaches depends on the location of the abscess and its progression. Empirical antibiotic therapy provides additional medical support and complements the surgical treatment.

\section{Conflict of interest}

The authors declare no conflict of interest.

\section{References}

1. Brook I. Current management of upper respiratory tract and head and neck infections. Eur Arch Otorhinolaryngol 2009; 266: 315-323.

2. Herzon FS, Martin AD. Medical and surgical treatment of peritonsillar, retropharyngeal, and parapharyngeal abscesses. Curr Infect Dis Rep 2006; 8: 196-202.

3. Brook I. Microbiology and management of peritonsillar, retropharyngeal, and parapharyngeal abscesses. J Oral Maxillofac Surg 2004; 62: 1545-1550.

4. Celakovsky P, Kalfert D, Smatanova K, Tucek L, Cermakova E, Mejzlik J, Kotulek M, Vrbacky A, Matousek P, Stanikova L, Hoskova T. Bacteriology of deep neck infections: analysis of 634 patients. Aust Dent J 2015; 60: 212-215.

5. Chang L, Chi H, Chiu NC, Huang FY, Lee KS. Deep neck infections in different age groups of children. J Microbiol Immunol Infect 2010; 43: 47-52.

6. Lee YQ Kanagalingam J. Bacteriology of deep neck abscesses: a retrospective review of 96 consecutive cases. Singapore Med J 2011; 52: 351-355.

7. Hasegawa J, Hidaka H, Tateda M, Kudo T, Sagai S, Miyazaki M, Katagiri K, Nakanome A, Ishida E, Ozawa D, Kobayashi T. An analysis of clinical risk factors of deep neck infection. Auris Nasus Larynx 2011; 38: 101-107.

8. Gupta M, Singh V. A retrospective study of 256 patients with space infection. J Maxillofac Oral Surg 2010; 9: 35-37. 
9. Kalmovich LM, Gavriel H, Eviatar E, Kessler A. Accuracy of ultrasonography versus computed tomography scan in detecting parapharyngeal abscess in children. Pediatr Emerg Care 2012; 28: 780-782.

10. Huang TT, Tseng FY, Liu TC, Hsu CJ, Chen YS. Deep neck infection in diabetic patients: comparison of clinical picture and outcomes with nondiabetic patients. Otolaryngol Head Neck Surg 2005; 132: 943-947.

11. Huang TT, Liu TC, Chen PR, Tseng FY, Yes TH, Chen YS Deep neck infection: analysis of 185 cases. Head Neck 2004; 26: 854-860.

\section{Address for correspondence:}

Katarzyna Justyna Błochowiak, PhD, DDS

Department of Oral Surgery

Poznan University of Medical Sciences

70 Bukowska St.

60-812 Poznan, Poland

Phone: +486185470 77

Fax: +48 618547016

Email: kasia@naszdentysta.com.pl 